DOI 10.22460/jpmi.v1i3.219-228

\title{
ANALISIS KESULITAN KEMAMPUAN KONEKSI MATEMATIS SIWA SMP KELAS VIII PADA MATERI BANGUN DATAR
}

\author{
Nurainah $^{1}$, Risna Maryanasari ${ }^{2}$, Puji Nurfauziah $^{3}$ \\ 1,2,3 IKIP Siliwangi, J1. Terusan Jenderal Sudirman, Cimahi, Jawa Barat, Indonesia \\ ${ }^{1}$ nurai7458@gmail.com, ${ }^{2}$ Risnamaryanasari@gmail.com, ${ }^{3}$ puji_fauziahahmad@ikipsiliwangi.ac.id
}

\begin{abstract}
The aim of this research is to describe about mathematical connection ability on two dimentional figure topic . Descriptive qualitative is the method are using in this research. The subject of this research are 39 students from VIII grade students of SMPN 7 Cimahi. The instrument of mathematical connection ability is test instrument based on indicators mathematical connection ability. Based on data analysis that dominate with good indicator of student ability to use Connections among students ability to recognize the relationships of different subjects in mathematics and to use mathematics in everday life, as well as students experiencing difficulties in connection indicators in using mathematics in other studies.
\end{abstract}

Keywords: mathematical connection, material wake flat, qualitative descriptive

\begin{abstract}
Abstrak
Penelitian ini bertujuan untuk mendeskripsikan kemampuan koneksi matematis siswa pada pokok bahasan bangun datar. Metode penelitian ini merupakan kualitatif deskriptif, dengan mendeskripsikan indikator kemampuan koneksi matematis mana saja yang paling mudah dan sukar untuk dikuasai siswa. Subjek dari penelitian ini adalah Siswa kelas VIII SMPN 7 Cimahi sebanyak 39 siswa. Insteumen yang digunakan yaitu soal tes kemampuan komunikasi matematik yang mengacu pada indikator kemampuan koneksi matematik. Berdasarkan analisis data bahwa siswa menguasai dengan baik indikator kemampuan koneksi dalam kemampuan siswa dalam mengenali hubungan pokok bahasan yang berbeda dalam matematika, dan menggunakan matematika dalam kehidupan sehari-hari, serta siswa mengalami kesusahan pada indikator koneksi dalam menggunakan matematika dalam studi lainnya.
\end{abstract}

Kata Kunci: Kemampuan Koneksi Matematis, Materi Bangun Datar, Kualitatif Deskriptif

How to cite: Nurainah, Maryana, S., \& Nurfauziyah, P. (2018). Analisis Kesulitan Kemampuan Koneksi Matematis Siwa SMP Kelas VIII pada Materi Bangun Datar. JPMIJurnal Pembelajaran Matematika Inovatif, 1 (1), 61-68.

\section{PENDAHULUAN}

Pembelajaran matematika memerlukan ketekunan dan keuletan, sehingga banyak siswa yang menggangap bahwa matematika itu pelajaran yang membosankan dan menyeramkan. Sebagaimana dikemukakan oleh Mulyono (Abdurrahman, 2012) menyatakan bahwa dari beberapa bidang studi di sekolah yang paling dianggap sulit oleh siswa yaitu pelajaran matematika baik yang tidak sulit untuk mempelajarinya dan bagi siswa yang sulit untuk mempelajarinya. 
Mata pelajaran matematika saling berkaitan anatara materi satu dengan materi lainnya. Keterkaitan tersebut tidak hanya antar toik dalam matematika tetapi keterkaitan dengan disiplin ilmu lain dan dengan kehidupan sehari-hari. sejalan dengan dalil pengaitan Bruner (Septiati, 2012) yang mengungkungkapkan bahwa dalam matematika tidak hanya konsep matematika saja tetapi berkaitan dengan konsep ilmu lain. Begitu juga dengan yang lainnya misalnya, antar dalil dan dalil, antar teori dengan teori antar konsep dengan konsep, antara topik dengan topi, maupun antar matematika dengan cabang matematika lain. Rendahnya tingkat keberhasilan siswa dalam pembelajaran matematika terdiri dari beberapa faktor yaitu sulitnya siswa dalam menerima materi matematika dan faktor ketidakmampuan siswa dalam memecahkan masalah matematika. Pentingnya pembelajaran matematika dalam kehidupan sehari-hari siswa, maka penting lah jika suatu pembelajaran dikaitkan dengan suatu kemampuan yang berkaitan dengan kehidupan sehari-hari yaitu kemampuan koneksi matematis.

Nurfauziah (2012) menyatakan bahwa kemampuan koneksi matematis adalah kemampuan siswa dalam mengenali hubungan pokok bahasan yang berbeda dalam matematika, menggunakan matematika dalam studi lainnya, dan menggunakan matematika dalam kehidupan sehari-hari. Selain dari hal tersebut, Dewi (2013) mengungkapkan bahwa kemampuan koneksi matematis adalah kemampuan mengaitkan konsep-konsep matematika baik antar konsep matematika itu sendiri maupun mengaitkan konsep matematika dengan bidang lainnya (luar matematika). Maka dari itu kemampuan koneksi matematis merupakan suatu kemampuan yang penting dalam pembelajaran matematika masa kini. Selain untuk mencapai tujuan pembelajaran, siswa dapat pandai dalam mengkoneksikan matematika dalam kehidupan sehari-hari.

Sedangkan menurut Linto, Elniati, dan Rizal (2012) menyatakan bahwa kemampuan koneksi matematis adalah kemampuan siswa dalam memecahkan persoalan-persoalan matematika mengenai materi yang diberikan sebelumya. Dalam kemampuan koneksi matematis ada 3 aspek yaitu:koneksi antar topik matematika, koneksi dengan disiplin ilmu yang lain, dan koneksi dengan kehidupan sehari-hari.

Berdasarkan beberapa pengertian kemampuan koneksi diatas dengan beberapa indikator maka dapat disimpulkan bahwa indikator yang diambil yaitu berdasarkan Nurfauziah (2012). Tetapi pada kenyataanya kemampuan koneksi matematis siswa masih sangat rendah. Berdasarkan penelitian yang dilakukan oleh Nola Nari and Putra Musfika (2017) ditemukan bahwa kemampuan koneksi matematis dalam pembelajaran masih rendah, karena dalam proses pembelajaran siswa tidak mampu mengaitkan materi sebelumnya dengan konsep matematika yang akan dipelajari. Penelitian Sholekah, Anggraeni dan Wahyono (2017) mengemukakan bahwa masih banyak siswa yang mengalami kesulitan dalam menyelesaikan soal kemampuan koneksi matematis sehingga prestasi siswa rendah. Selain itu Warih, Parta dan Rahardjo (2016) juga menyatakan bahwa kemampuan koneksi matematis siswa di sekolah masih sangat rendah dikarenakan siswa masih belum mempu dalam melakukan pengoneksian secara maksimal.

Untuk mengetahui kelemahan siswa dalam kemampuan koneksi matematis maka peneliti akan meneliti kesulitan siswa pada kemampuan koneksi matematis siswa kelas VIII di SMPN 7 Cimahi. Hasil dari penelitian diharapkan dapat menjadi acuan guru untuk melakukan suatu tindakan terhadap siswa yang berkaitan dengan kemampuan koneksi matematis yang memadai. Peneliti mengambil materi Bangun Datar karena materi tersebut berkaitan dengan kehidupan sehari-hari serta berkaitan dengan masalah-masalah kehidupan yang dialami siswa. Oleh karna itu siswa dapat mengatasi suatu masalah secara sistematis melalui materi bangun datar. 
Penelitian ini bertujuan untuk Mengkategorikan tingkat kemampuan koneksi matematis siswa kelas VIII SMPN 7 Cimahi serta untuk mengetahui kinerja siswa dalam proses penyelesaian soal dalam masing-masing indikator kemampuan koneksi matematis siswa. Sehingga akhirnya dapat menemukan suatu inovasi baru dalam pembelajran matematika yang dapat bermanfaat bagi semua kalangan

\section{METODE}

Penelitian ini adalah penelitian deskriftif kualitatif untuk menganalisis kemampuan koneksi matematis siswa. Sampel sebanyak 39 siswa kelas VIII SMPN 7 Cimahi.

Instrumen yang digunakan adalah instrumen tes yang terdiri dari 5 soal materi bangun datar yang memuat indikator kemampuan koneksi matematis yang telah teruji content validity-nya. Instrument tes digunakan untuk mendapatkan hasil pekerjaan siswa dalam menyelesaikan soal kemampuan koneksi matematis siswa. Hasil tes kemampuan koneksi selanjutnya dianalisis dan dideskripsikan berdasarkan pada indikator kemampuan koneksi matematis yang paling dikuasai dan yang tidak dikuasai oleh siswa.

Untuk melihat pencapaian kemampuan koneksi matematis siswa yaitu: 1) dilihat dengan cara membandingkan nilai kemampuan koneksi matematis pada pokok bahasan bangun datar dengan nilai KKM (Kriteria Ketuntasan Minimum). Kita dapat melihat dengan mengelompokan nilai siswa yang diatas KKM Sebanyak berapa orang dan mengelompokan siswa yang mendapatkan nilai di bawah kkm berapa orang, dengan rumus:

Nilai diatas KKM $=\frac{\text { jumlah siswa dengan nilai diatas KKM }}{\text { Jumlah seluruh siswa }} \times 100 \%$
Nilai dibawah KKM $=\frac{\text { jumlah siswa dengan nilai dibawah KKM }}{\text { Jumlah seluruh siswa }} \times 100 \%$

2) berdasarkan indikator kemampuan koneksi matematis siswa yang selanjutnya akan dideskripsikan berdasarkan indikator yang paling dikuasai dan yang tidak dikuasai siswa.

\section{HASIL DAN PEMBAHASAN}

\section{Penilaian dilihat dari KKM}

Berdasarkan rumu diatas maka hasil dari pelilaian berdasarkan KKM didapat ;

Nilai diatas KKM $=\frac{\text { jumlah siswa dengan nilai diatas KKM }}{\text { Jumlah seluruh siswa }} \times 100 \%$

$$
\frac{17}{39} \times 100 \%=43,6 \%
$$

Nilai dibawah KKM $=\frac{\text { jumlah siswa dengan nilai dibawah KKM }}{\text { Jumlah seluruh siswa }} \times 100 \%$

$$
\frac{22}{39} \times 100 \%=56,4 \%
$$

Berdasarkan hasil persentase di atas maka dapat disimpulkan bahwa siswa dalam mengerjakan soal kemampuan koneksi tersebut sebagaian besar tidak mencapai KKM yang ditentukan. Dengan rincian presentase siswa yang mendapatkan nilai di bawah KKM adalah 56,4\%. Dan siswa yang mendapatkan nilai diatas KKM adalah 43,6\%. Jadi data diatas bahwa mayoritas siswa memiliki nilai dibawah KKM, artinya siswa memiliki nilai dibawah 75 dalam menyelesaikan soal kemampuan koneksi matematis dan hal tersebut sesuai dengan kemampuan 
koneksi matematis perindikator. Walaupun mayoritas siswa berada dibawah KKM tetapi perbedaan dengan yang dibawah KKM hanya $12,8 \%$ saja.

2. Dilihat dari indikator Kemampuan Koneksi Matematis

Tabel 1 persentase kemampuan koneksi matematis berdasarkan indikator

\begin{tabular}{clc}
\hline No & \multicolumn{1}{c}{ Indikator Kemampuan Koneksi Matematis } & Persentase \% \\
\hline 1 & $\begin{array}{l}\text { kemampuan siswa dalam mengenali hubungan pokok } \\
\text { bahasan yang berbeda dalam matematika. }\end{array}$ & $68,27 \%$ \\
\hline 2 & menggunakan matematika dalam studi lainnya. & $30,13 \%$ \\
\hline 3 & $\begin{array}{l}\text { menggunakan matematika dalam kehidupan sehari- } \\
\text { hari. }\end{array}$ & $66,11 \%$ \\
\hline
\end{tabular}

Berdasarkan tabel diatas dapat diketahui bahwa penguasaan siswa terhadap indikator 1 dan 3 adalah $(68,27 \%)$ dan $(66,11 \%)$. Sedangkan penguasaan siswa terhadap indikator 2 adalah $(30,13 \%)$. Dari nilai presentase tersebut dapat dikatakan bahwa siswa tidak menguasai indikator ke-2 kemampuan koneksi matematis. Indikator tersebut yaitu Menggunakan matematika dengan bidang studi lain.

Soal no 2

Pada suhu $27^{\circ} \mathrm{C}$, sebuah keping kaca yang berbentuk persegi panjang memiliki ukuran $5 \mathrm{~m} \mathrm{x}$ $6 \mathrm{~m}$. Berapakah luas keping kaca tersebut pada suhu $97^{\circ} \mathrm{C}$ jika koefisien muai luas kaca $=0,000$ $009 /{ }^{0} \mathrm{C}$.

Jawaban siswa

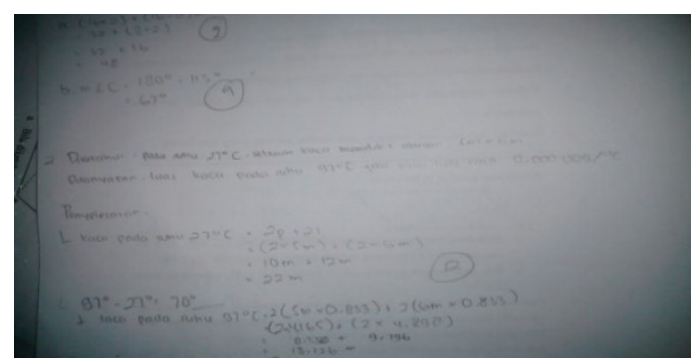

Gambar 1. Jawaban Siswa pada Indikator 2

Berdasarkan gambar 1, siswa sudah menuliskan mengenai yang diketahui dan mengenai yang ditanyakan dalam soal serta siswa juga telah menerapkan suatu konsep yang berkaitan dengan rumus persegi panjang, tetapi siswa kurang teliti dalam mengisi sehingga jawaban kurang tepat. Sehingga di peroleh suatu kesalahan konseptual.

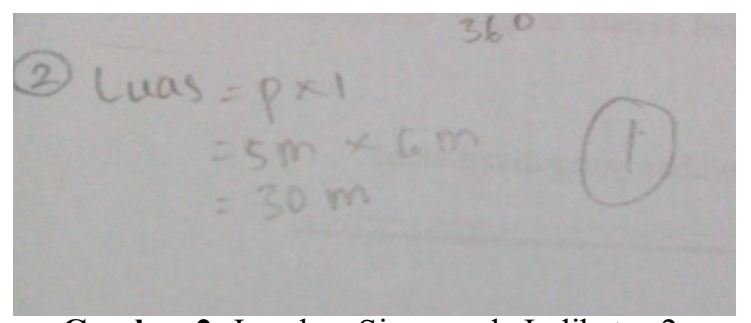

Gambar 2. Jawaban Siswa pada Indikator 2

Berdasarkan gambar 2,siswa tidak menuliskan mengenai apa yang di ketahui serta yang ditanyakan pada soal karna pada dasarnya jika siswa menulis diketahui dan ditanyakan pada soal maka siswa tersebut sudah memahami soal tersebut, sehingga diperoleh informasi bahwa 
siswa mengalami kesalahan prosedural. Di samping itu siswa pun langsung mengisi jawaban dan langsung menerapkan rumus luas persegi panjang tanpa memahami menerapkan konsep. Sehingga diperoleh informasi bahwa siswa melakukan kesalahan konseptual.

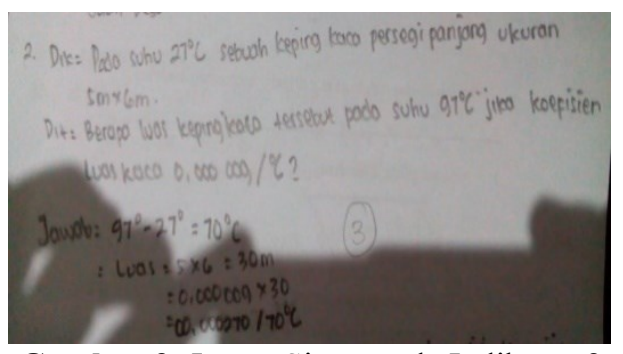

Gambar 3. Jawan Siswa pada Indikator 2

Berdasarkan gambar 3, siswa sudah menuliskan mengenai yang diketahui dan yang ditanyakan berdasarkan soal serta siswa telah memahami konsep dengan menerapkan rumus persegi panjang dan hasil jawaban siswa sudah mendekati jawaban sempurna, tetapi jawaban kurang tepat. Sehingga diperoleh kesalahan siswa dalam konseptual.

Berdasarkan hasil analisis soal kemampuan koneksi matematis siswa dapat disimpulkan bahwa siswa mengalami kesulitan dalam soal cerita bangun datar persegi panjang sehingga siswa melakukan kesalahan. Kesalahan yang dilakukan siswa dalam menyelesaikan soal cerita bangun datar luas persegi panjang yaitu kesalahan konseptual dan prosedural. Kesalahan konseptual yang dimaksudkan disini yaitu siswa salah dalam menerapkan konsep yang ada pada materi bangun datar luas persegi panjang dengan menggunakan soal cerita. Sejalan dengan Wijaya (2013) yang menyatakan bahwa kesalahan konsep siswa dalam menyelesaikan soal cerita. Selanjutnya sejalan dengan pernyataan Sulistyowati (2014) yang menyatakan bahwa siswa dikatakan melakukan kesalahan konsep siswa ketika menuliskan rumus dengan benar. Sedangkan kesalahan prosedural yaitu siswa tidak mencantumkan secara lengkap hal yang diketahui dan hal yang ditanyakan dan siswa salah dalam langkah-langkah menyelesaikan soal (Rahmi, Nadia, Hasibah, \& Hidayat, 2017). Sejalan dengan Kastolan (Sahriah:2012) yang menyatakan bahwa kesalahan prosedural yaitu kesalahan ketika siswa menyusun langkahlangkah penyelesaian dalam menyelesaikan masalah.

Jadi berdasarkan hasil jawab siswa yang ditampilkan pada beberapa gambar diatas maka dapat dikatakan bahwa siswa tidak memahami permasalahan yang diberikan mengenai materi bangun datar yang dikaitkan dengan mata pelajaran yang lain. Hal tersebut dikarenakan siswa tidak memahami konsep tersebut walaupun sudah diberikan gambaran mengenai konsep tersebut. Oleh karena itu seharusnya siswa diberikan soal terapan yang berhubungan dengan mata pelajaran lain ketika dalam latihan soal.

\section{KESIMPULAN}

Ditinjau dari pencapaian kemampuan koneksi matematis siswa pada setiap indikator pada materi bangun datar paling tinggi tercapai pada indikator 1 yaitu Mencari hubungan antar refresentasi dan prosedur serta memahami konsep matematis kemampuan siswa dalam mengenali hubungan pokok bahasan yang berbeda dalam matematika, dan indikator 3 yaitu menggunakan matematika dalam kehidupan sehari-hari. Sedangkan pencapaian yang paling rendah yaitu pada indikator 2 yaitu Menggunakan matematika dengan studi lain. 


\section{UCAPAN TERIMAKASIH}

Penulis menyadari dan merasakan sepenuhnya bahwa dalam pembuatan jurnal ini tidak terlepas dari bantuan, bimbingan, arahan, dan motivasi dari berbagai pihak. Penulis menyampaikan ucapan terima kasih kepada:

1. Bpk Wahyu Hidayat, S.Pd., M.Pd. sebagai dosen mata kuliah metode penelitian.

2. Ibu Puji Nurfauziah, S.Pd., M.Pd. sebagai dosen pembimbing jurnal.

3. Ibu Lilis Karmini, S.Pd., M.Pd. sebagai wakil kepala sekolah SMPN 7 Cimahi yang telah mengijinkan kami melakukan penelitian di sekolah tersebut.

4. Bpk Abu Muchlis, S.Pd., M.Pd. sebagai guru matemaika kelas VIII SMPN 7 Cimahi yang telah mengijinkan kami melakukan penelitian di sekolah tersebut.

5. Orang tua yang selalu mendo'akan kami dalam melakukan penelitian dan dalam pembuatan jurnal ini.

6. Semua pihak yang telah membantu dalam penyelesaian makalah ini, baik secara langsung maupun tidak langsung.

Semoga Allah SWT membalas kebaikan Bapak/Ibu dan saudara semua dengan pahala yang berlipat ganda. Amin.

Penulis juga mengharapkan masukan dan saran yang membangun dari pembaca, demi perbaikan jurnal ini, sehingga dapat memberikan sumbangsih dalam upaya meningkatkan kualitas pembelajaran matematika.

\section{DAFTAR PUSTAKA}

Abdurrahman, M. (2012). Anak berkesulitan belajar: teori, diagnosis, dan remediasinya. Jakarta: Rineka Cipta.

Dewi, N. R. (2013). Peningkatan Kemampuan Koneksi Matematis Mahasiswa Melalui BrainBased Learning Berbantuan Web. Makalah Pendamping: Pendidikan Matematika, 4(1).

Linto, R. L., Sri E., dan Yusmet R. (2012). "Kemampuan Koneksi Matematis dan Metode Pembelajaran Quantum Teaching Dengan Peta Pikiran”. Jurnal Pendidikan Matematika, $1(1), 83-87$.

Nari, N., \& Musfika, A. P. (2017). Analisis Kesulitan Belajar Ditinjau Dari Kemampuan Koneksi Matematika Peserta Didik. Procceding Iain, 1(2), 311-320. Batusangkar.

Nurfauziah, P. (2012). Peningkatan Kemampuan Koneksi Matematis dan Self-efficacy Siswa SMP Melalui Pembelajaran Matematika Model CORE (Dectoral dissertation, Universitas Pendidikan Indonesia).

Rahmi, S., Nadia, R., Hasibah, B., \& Hidayat, W. (2017). The Relation between Self-Efficacy toward Math with the Math Communication Competence. Infinity Journal, 6(2), 177182.

Sahriah. S, Muksar. M, \& Lestari. T. E. (2012). Analisis Kesalahan Siswa dalam Menyelesaikan Soal Matematika Materi Operasi Pecahan Bentuk Aljabar Kelas VIII SMP Negeri 2 Malang. Jurnal Pendidikan Matematika, 1(1).

Septiati, E. (2012). Keefektifan Pendekatan Kontruktivisme Terhadap Kemampuan Koneksi Matematis Mahasiswa Pada Mata Kuliah Analisis Real. In Prossiding Seminar Nasional Matematika dan Pendidikan Matematika FMIPA UNY, (Vol. 10). Yogyakarta 
Sholekah, L. M. A., \& Waluyo, A. (2017). Analisis Kesulitan Siswa Dalam Menyelesaikan Soal Matematika Ditinjau Dari Koneksi Matematis Materi Limit Fungsi. WACANA AKADEMIKA: Majalah Ilmiah Kependidikan, 1(2).

Sulistyowati, N., Suyatno, M. S., Poedjiastoeti, S., \& Si, M. (2014). Pembelajaran Kimia Dengan Model Learning Cycle 5E Untuk Meningkatkan Penguasaan Konsep dan Keterampilan Berfikir Kritis Siswa SMK Pada Pokok Bahasan Termokimia. Doctoral Dissertation, Tesis. Surabaya: Universitas Negeri Surabaya.

Warih, P. D. (2016). Analisis Kemampuan Koneksi Matematika Siswa Kelas VIII Pada Materi Teorema Pythagoras: Prosiding Konferensi Nasional Penelitian Matematika dan Pembelajarannya (KNPMP I), diselenggarakan oleh Program Studi Pendidikan Matematika, UMS, 12 Maret 2016, (hal. 377-384). Muhammadiyah University Press.

Wijaya, A. A. (2013). Analisis Kesalahan Siswa dalam Menyelesaikan Soal Cerita Materi Sistem Persamaan Dua Variabel. Mathedunesa, 2(1). 
